\title{
Effect of bentonite on the health and dairy production of cows submitted to a diet naturally contaminated by mycotoxins
}

\section{Efeito da bentonita na saúde e produção leiteira de vacas submetidas à dieta naturalmente contaminada por micotoxinas}

\author{
Mirodion Santos Oliveira1*; Dalvane Di Domenico"; Gabriela Rodrigues Thomaz²; \\ Gabriela Garbossa'; Carolina Rodrigues Depaoli2; Ana Carolina Araujo Abreu2; \\ Heloisa Godoi Bertagnon ${ }^{3}$
}

\section{Highlights}

Brazilian climate predisposes the contamination of the bovine diet by mycotoxins. Bentonites improved immunity of cattle exposed naturally produced mycotoxins. Bentonites increased milk production of cattle fed diets containing ZEA, FB and DON.

\begin{abstract}
Mycotoxins often contaminate cattle food, which can cause liver damage, immunosuppression, and reduced milk production. Although previous studies have shown the benefits of adsorbents in farm animals, knowledge regarding their mechanism of action is limited, especially when intoxication occurs due to naturally contaminated diets. The present study aimed to assess whether the daily oral administration of mycotoxin adsorbent bentonite clay based on aluminosilicate for 56 days, would attenuate these changes in 18 dairy cows, which were multiparous in the middle of the lactation stage, and were consuming a diet containing fumonisin B1 and B2, zearalenone, and desoxynivalenol. The animals were divided into treatment ( $T G, n=9$ ) and control (CG, $n=9$ ) groups, and subjected to assessment of liver functions, hematological assessments, assessment of oxidative leucocyte metabolism by the tetrazolium nitroazul (NBT) technique, and physical chemical analysis of milk, every week for two months, totaling eight analyses. It was observed that the use of the adsorbent caused a reduction in the milk excretion of aflatoxin M1 (AFM1), an increase in levels of serum protein $(p=0.03)$ and albumin $(p=0.0001)$, an increase in leukocyte oxidative metabolism

1 Master in Veterinary Science, Universidade Estadual do Centro-Oeste, UNICENTRO, Guarapuava, PR, Brazil. E-mail: mirodion@gmail.com; dalvanedidomenico@gmail.com; gabigarbossa@hotmail.com.

2 Students of Veterinary Medicine, UNICENTRO, Guarapuava, PR, Brazil. E-mail: thomaz.grt@gmail.com; depaolicarolina@yahoo.com; anacarolinaaabreu@gmail.com.

3 Profa Dra, Postgraduate Program in Veterinary Sciences, UNICENTRO, Guarapuava, PR, Brazil. E-mail: hbertagnon@ hotmail.com

* Author for correspondence
\end{abstract}

Received: Apr. 27, 2021 - Approved: July 01, 2021 
from day 24 of treatment $(p=0.05)$, and increased milk production from the day 16 of treatment $(p=0.08)$. There was no improvement in the physicochemical indices of the milk. It was concluded that the use of an aluminosilicate-based adsorbent was able to attenuate the effects of mycotoxins on the function of leukocytes and increase milk production.

Key words: Adsorbent. Aflatoxin. Cattle. Immunity. Milk.

\section{Resumo}

Micotoxinas podem contaminar alimentos de bovinos, levando a distúrbios hepáticos, imunodepressão e redução da produção. Embora existam estudos mostrando os benefícios de adsorventes em animais de produção, há limitado conhecimento sobre sua ação quando a intoxicação de bovinos ocorre por dietas naturalmente contaminadas. O presente estudo objetivou avaliar se a administração oral diária do adsorvente de micotoxinas, argila bentonita a base de aluminossilicato durante 56 dias atenuaria alterações promovidas pelas micotoxinas em 18 vacas leiteiras, multíparas no meio do estágio da lactação, consumindo dieta contendo fumonisina B1 e B2, zearalenona (ZEA) e desoxinivalenol (DON). Os animais foram divididos, grupos tratamento $(G T, n=9)$ e controle $(G C, n=9)$, e submetidos às avaliações de enzimas e função hepática, hematológicas, metabolismo oxidativo de leucócitos pela técnica do nitroazul de tetrazolium (NBT) e análise físico-química do leite, a cada semana, durante dois meses, totalizando oito análises. Observou-se que o uso do adsorvente promoveu redução da excreção láctea de aflatoxina M1 (AFM1), aumento de proteína ( $p=0,03)$ e albumina séricas $(p=0,0001)$, e aumento do metabolismo oxidativo leucocitário a partir do dia $24(p=0,05)$. Houve também elevação da produção leiteira a partir do $16^{\circ}$ dia de tratamento $(p=0,008)$. Não foi observado melhora nos índices físico-químicos do leite dos animais e houve pouca influência na atividade das enzimas hepáticas. Conclui-se que o uso do adsorvente a base de aluminossilicato foi capaz de atenuar os efeitos das micotoxinas na função de leucócitos e de elevar a produção leiteira.

Palavras-chave: Adsorvente. Aflatoxinas. Bovinos. Imunidade. Leite.

\section{Introduction}

One of the factors impacting dairy production is the presence of mycotoxins, a contamination of great concern to public and animal health (Dawson, Evans, \& Kudupoj, 2006). Mycotoxins are produced by fungi, which are microorganisms usually found in products intended for animal and human consumption (Bennett \& Klich, 2003). In cattle, the most studied mycotoxin is aflatoxin (AF), the only one that produces thermostable, active metabolites excreted through milk, with carcinogenic potential (Murphy, Hendrich, Landgren, \& Bryant, 2006; Kutz et al., 2009).
However, other mycotoxins, such as fumonisin (FB), zearalenone (ZEA), and deoxynivalenol (DON), have also been reported to cause liver lesions, immunosuppressive effects, and lower milk yield (Oswald et al., 2005).

In Brazil, contamination of substrates by mycotoxin-producing fungi is common due to climatic conditions, resulting in ZEA and FB contamination in corn grain, and AF, ZEA, FB, and $D O N$ contamination in corn silage between 2018 and 2020 (Dadalt \& Primieri, 2020; Tyska el al., 2021). Thus, the impact of mycotoxins on human and animal health has motivated the developmentofadsorbentsand otherproducts 
capable of neutralizing the toxins, that pass through the gastrointestinal tract (Dawson et al., 2006). As there are no ideal adsorbents for all mycotoxins, most studies have focused on the effects of isolated inorganic adsorbents or in association with organic adsorbents, to decrease the absorption of mycotoxins by the gastrointestinal tract in cattle experimentally intoxicated with mycotoxins (Kutz et al., 2009; Kiyothong, Rowlinson, Wanapat, \& Khampa, 2012; Jovaisiene, Bakutis, Baliukoniene, \& Gerulis, 2016).

In these studies, though, the animals were intoxicated with high doses of only one mycotoxin, which may not represent natural intoxication, where there are several mycotoxins in low doses acting synergistically (Custódio et al., 2019). In addition, few studies have analyzed the effects of mycotoxin adsorbents on the innate immune function of cattle (Migliorati, Abeni, Cattaneo, Tornielli, \& Pirlo, 2007; Jovaisiene et al., 2016; Xiong, Wang, Zhou, \& Liu, 2018).

Among the inorganic adsorbents, bentonites, which are clay ores of the smectite family, are widely used because of their low cost and effective adsorption of mycotoxins, especially AF (Schneider, Mayer, Volpato, \& Gewehr, 2019), although their adsorption of ZEA and DON is questionable (Sabater-Vilar, Malekinejad, Selman, \& Van Der Doelen, 2007).

Due to this economic advantage, the present study sought to verify whether the use of inorganic bentonite adsorbent based on aluminosilicate in animal feed can improve liver health, leukocyte oxidative metabolism, and the quality and quantity of dairy production in dairy cows that were fed a diet naturally contaminated with mycotoxins.

\section{Materials and Methods}

The experiment was approved by the ethics and animal experimentation committee of UNICENTRO (005/2020). The experimental design was completely randomized, performed using a blind study model for evaluation in relation to the treatment, for two months.

In this experiment, 18 cows and dairy heifers (Holstein breed) were used while they were in the middle of the lactation stage, with a daily production average of $29 \mathrm{~L}$ of milk, from two mechanical milkings. The cows were from a dairy property, located in the district of Jordão in Guarapuava, PR, comprising of 60 lactating animals confined in a compost bedded pack barn system. The same food regime was adopted 3 years ago at the property, and cattle were fed three times a day with $14.8 \mathrm{~kg}$ total feed, composed of $60 \%$ corn silage, 23\% commercial concentrate (Leite Max Avant ${ }^{\circledR}$ 20T GP, Cooperativa AGRÁRIA), $2 \%$ soybean meal, $14 \%$ pre-dried oatmeal and $1 \%$ mineral nucleus. The food was stored at the property, and the same lot was used throughout the experiment. The feed was provided in a treatment room, with free access to the animals, located next to the animal's rest shed in an open feeder system. Food management was the will with leftovers between approximately $2 \%$ and $5 \%$ of the volume offered.

The animals were divided into two homogeneous groups, considering milk volume and somatic cell count (SCC). These two groups were control group $(\mathrm{CG} / \mathrm{n}=9)$, fed diet without mycotoxin adsorbent, and treatment group (TG/n=9), fed diet containing mycotoxin adsorbent. Each group consisted of four multiparous cows, with an average 
production of $24 \mathrm{~L}$ day $^{-1}$, including one cow with high SCC (above 500 thousand $\mathrm{g} \mathrm{mL}^{-1}$ ) and five cows with average production above $30 \mathrm{~L} \mathrm{day}^{-1}$, with low SCC.

The TG received $30 \mathrm{~g}$ animal ${ }^{-1}$ per day of the product based on bentonite clay- (aluminiosilicate, $900 \mathrm{~g} \mathrm{Kg}^{-1}$; Biobond RM,Pegmatech ${ }^{\circledR}$, São Paulo, SP. Brazil) for 56 days. The product was directly added to the trough in the total feed along with a small portion of concentrate (approximately $50 \mathrm{~g}$ ) in the morning, ensuring that the cows ingested the product at the time when the feeder was closed. Later, the feeder was opened, and the rest of the total ration was administered. The animals in the $C G$ received a diet similar to that of TG, but without the added product or some placebo substance.

At weekly intervals, for two months on days D0, D8, D16, D24, D32, D40, D48, and D56, blood and milk samples were collected from the animals. Blood samples were collected by superficial epigastric breast venopuncture, and packed in vacuum plastic tubes containing heparin, EDTA, and without anticoagulant, to evaluate the oxidative metabolism of leukocytes, perform blood count, and analyze injury and liver function.

For the evaluation of liver function, serum was extracted from whole blood after centrifugation at 3000/rpm for $15 \mathrm{~min}$ at room temperature. Subsequently, total serum protein, albumin, and enzyme activity were measured. In case of enzyme activity, specifically, aspartate aminotransferase (AST) and gamma glutamyl transferase (GGT) activities were measured by biochemical tests using the methodology of decreasing kinetic and colorimetric reaction, in a semi-automatic device (Bioplus ${ }^{\circledR}$ ), using commercial kits (total proteins, albumin, AST/GOT Liquiform, GAMA GT Liquiform, Labtest ${ }^{\circledR}$ Diagnóstica S.A., Lagoa Santa, MG, Brazil).

Oxidative metabolism was assessed by the colorimetric technique of reduction of nitroblue latrazolium (NBT), as described by Choi, Kim, Cha and Kim (2006), adapted by Flores et al. (2019). For this, the blood was refrigerated until it was processed within a maximum of $3 \mathrm{~h}$ after harvest. Briefly, $100 \mu \mathrm{L}$ of whole blood was incubated with equal parts of NBT solution (Sigma ${ }^{\circledR}$, São Paulo, Brazil) at $1 \%$ and $5 \mu \mathrm{L}$ of 12 -myristate-13-forbo acetate (PMA at $300 \mathrm{ng} \mathrm{mL}^{-1}$, Sigma ${ }^{\circledR}$ ). After incubation the reaction was interrupted by the addition of $2000 \mu \mathrm{L}$ of ice-cold EDTA ( $3 \mathrm{mM}$ ), and red blood cells were subjected to osmotic lysis. Then, the external NBT was removed by washing and centrifugation at $1200 \mathrm{rpm}$ for $8 \mathrm{~min}$ at $4^{\circ} \mathrm{C}$, the supernatant was discarded, and the leukocyte pellet was fixed with methanol (1 mL Synth ${ }^{\circledR}$, São Paulo, Brazil). The cells were then dissolved in $\mathrm{KOH}$ (Synth ${ }^{\circledR}$ São Paulo, Brazil) (3 M, $120 \mu \mathrm{L}$ ) and DMSO (Dimesol ${ }^{\circledR}$ - MarcoLab, São Paulo, Brazil) (99\%, $140 \mu \mathrm{L})$, and the suspension was analyzed using spectrophotometry at $630 \mathrm{~nm}$ (Thermo Plate ${ }^{\circledR}$, São Paulo, Brazil) in duplicates, with intravarivariability confidence lower than $0.05 \%$.

The blood count was performed using an automatic hematology counter (SDH3 VET, Labtest ${ }^{\circledR}$ São Paulo, Brazil), and the differential leukocyte count was performed using blood smears, considering morphological and metric characteristics in optical microscopy.

Milk collection was performed directly on the milking line (closed system) in tubes containing bronopol. For each animal, an individual milk sample was collected from the four teats at each time point and sent for 
the measurement of the levels of lactose, fat, protein, defatted dry extract (ESD), and SSC at the Associação paranaense de criadores de bovinos da raça holandesa (APCBRH PARLPR, Curitiba, Brazil).

At D0, D24, and D56, approximately $55 \mathrm{~mL}$ of milk from each animal in each group was collected to make up the milk pool of each group to measure AF in milk. Samples of 500 $\mathrm{ml}$ of milk from each group were frozen at $-8^{\circ} \mathrm{C}$ until processing.

Samples of corn silages, pre-dried oats, soybean meal, and concentrate were collected in plastic bags at three different points, so that the collection totaled at least $500 \mathrm{~g}$ at two different times, specifically, at the beginning and in the middle of the experiment. The food and milk pools of each group were sent on ice to the laboratory Lamic SAMITEC (Santa Maria, RS, Brazil) for the detection and quantification of mycotoxins, with AFM1 levels being measured in milk and AFG1, AFG2, AFB1, AFB2, FB1, FB2, ZEA, and DON levels being measured in food. In milk, for the measurement of AFM1 levels, the quantification limit was $0.0025 \mu \mathrm{g} \mathrm{L}^{-1}$, and in food, for the measurement of $A F, F B, D O N$, and ZEA levels by liquid chromatographysequential mass spectrometry (LC-MS/ $M S)$, the following detection limits (LOD) and quantification limits (LOQ) were set: 1.4 and 5.0; 200 and 500; 100 and 500; and 10 and 25 $\mu \mathrm{K} \mathrm{Kg}^{-1}$, for AF, FB, DON, and ZEA, respectively. The levels of mycotoxins in the food were expressed as the average of the two values calculated (beginning and in the middle of the experiment).

\section{Statistical analysis}

The data were analyzed using the statistical software Instat Graphpad and were represented as mean \pm standard error. For the evaluation of the interaction time, the means of the results were analyzed by the parametric one-way analysis of variance (ANOVA) (Unstacked) test for repeated samples, followed by the Tukey test. As for the interaction of the treatment, the means of the results were analyzed using the parametric t-test for unpaired samples. The CCS variable had a non-normal distribution and was therefore transformed into log 10 and analyzed by the parametric tests described above. For each analysis, a statistical significance of $5 \%$ ( $p<0.05$ ) was considered (Sampaio, 2002).

\section{Results and Discussion}

Our results show that in cattle that were fed with a diet containing naturally produced mycotoxins FB, ZEA, DON, and PA, the daily administration of bentonite was able to decrease the milk excretion of AFM1, and hence could be beneficial to animal health and dairy production, as discussed below.

Table 1 shows the results of the analyses of food and mycotoxins. 
Table 1

Chemical composition of food used in animal feed and the amount of mycotoxins detected

\begin{tabular}{|c|c|c|c|c|c|}
\hline Parameter & Corn silage & Concentrated & Soybean meal & Pre-dried oats & Mixture \\
\hline DM \% & 42 & 87,5 & 89 & 53,7 & 68,51 \\
\hline MM \% DM & 3,49 & 8 & 6,84 & 6,5 & 7,05 \\
\hline CP \% DM & 7,98 & 20 & 49,72 & 9,2 & 16,7 \\
\hline EE\% DM & 3,57 & 4,8 & 4,51 & 5,0 & 4,7 \\
\hline NDF \% DM & 35,01 & & 9,28 & 64,2 & - \\
\hline ADF \% DM & 21,03 & 12 & 7,76 & 38,9 & 19,86 \\
\hline TDD \% DM & 76,39 & 84 & 4,45 & 60,61 & 67,79 \\
\hline FB1 $\mu \mathrm{gKg}^{-1}$ & 435,4 & 400,1 & 125 & ND & 683,7 \\
\hline FB2 $\mu \mathrm{g} \mathrm{Kg}^{-1}$ & 158,9 & 125 & ND & ND & 306,6 \\
\hline ZEA $\mu \mathrm{gKg}^{-1}$ & 514,9 & ND & 36,1 & ND & 503,9 \\
\hline $\mathrm{DON} \mu \mathrm{gKg}^{-1}$ & 260,3 & 1773,4 & ND & ND & 724,61 \\
\hline $\mathrm{AF} \mu \mathrm{g} \mathrm{Kg}^{-1}$ & ND & ND & ND & ND & ND \\
\hline
\end{tabular}

$\mathrm{DM}=$ dry matter; $\mathrm{MM}=$ mineral matter; $\mathrm{CP}=$ crude protein; $\mathrm{EE}=$ ether extract; $\mathrm{NDF}=$ neutral detergent fiber; $\mathrm{ADF}=$ acid detergent fiber; TDD= total digestible nutrients; $p p b=$ parts per billion; ND = not detected. FB- fumonisin ,ZEAzearalenone ,AF-aflatoxin.

It was observed that the total feed used contained several mycotoxins at levels that are considered challenging, based on the limits set by the Forage IPR Research Center of UFPR, which recommends diet indexes lower than 1,000 ppb for $\mathrm{FB}, 930 \mathrm{ppb}$ for $\mathrm{DON}$, and $285 \mathrm{ppb}$ for ZEA, for corn silage. Although only ZEA levels were above the recommended limit, FB levels were very close to the recommended limit. In addition, the limits recommended as ideal are only for corn silage and not for the total diet. It is also worth mentioning that mycotoxins can act synergistically and accentuate their toxic effects (Custódio et al., 2019; Dadalt \& Primieri, 2021).

AF was not detected in the total food or feed; however, there was excretion of its metabolite, $A F M_{1}$, in the milk pool of cows (Table 2), and the maximum observed value was $0.009 \mu \mathrm{g} \mathrm{Kg}^{-1}$ of fluid milk, which confirms to the recommended Normative Instruction No. 88/2021 of the National Health Surveillance Agency/ANVISA, which specifies a maximum limit of $0.5 \mu \mathrm{\mu g} \mathrm{kg}^{-1}$ (Intrução normativa $\left.n^{\circ} 88,2021\right)$. According to Wang et al. (2019), the levels of AFM 1 excreted in milk may remain significant even after the end of the consumption of $\mathrm{AFB}_{1}$; thus, in the experiment, cows fed a diet containing $20 \mu \mathrm{g}$ $\mathrm{kg}^{-1}$ or $40 \mu \mathrm{g} \mathrm{kg}^{-1}$ of $A F B_{1}$ showed presence of $\mathrm{AFB}_{1}$ in milk 1 to 3 days after the end of the consumption of the diet. However, there was no significant difference in the concentration of $\mathrm{AFM}_{1} 7$ days after the beginning of the clearance period. As $A_{F M}$ is derived directly from the hydrolysis of $A F B_{1}$ by the liver, and is excreted through milk, it was concluded that the diet contained AFB 1 (Cano-Sancho, Marin, Ramos, Peris-Vicente, \& Sanchis, 2010). This has already been reported by Pereira et al. 
(2005). In their experiment, while none of the 33 animal food samples analyzed were found to contain FA, there were detectable levels of FA in milk. Studies indicate that the pass rate from $A F B_{1}$ to $A F M_{1}$ is 0.3 to $6.2 \%$, and that its levels are not affected by pasteurization or sterilization (Prandini et al., 2009). Because this was a milk pool, no statistical analysis of this variable was performed. But numerically, it is possible to show that bentonite reduced AFM $_{1}$ excretion.

\section{Table 2}

Aflatoxin M1 contents in the milk pool of untreated cows (CG) and treated with mycotoxin adsorbent (TG)

\begin{tabular}{cccc} 
Aflatoxin $\mathrm{M}_{1} \mu \mathrm{Kg} \mathrm{Kg}^{-1}(\mathrm{ppb})$ & \multicolumn{3}{c}{ Moments } \\
\cline { 2 - 4 } CG & D0 & D24 & D56 \\
TG & 0,009 & 0,009 & 0,008 \\
\end{tabular}

$\mathrm{ppb}=$ parts per billion

$\mathrm{AFM}_{1}$ is the only mycotoxin measured in animal milk so far, so its decrease in the TG animals indicates that the adsorbent was able to remove at least this toxin from the diet, showing its effectiveness. As for the mechanism of action of inorganic adsorbents, the mycotoxins bind to these adsorbents by means of electrical charges, preventing them from being absorbed by animals, and leading to their elimination through feces (Franciscato et al., 2006). In in vivo tests, AF is successfully adsorbed by organic and inorganic adsorbents; however, DON and FB are adsorbed less efficiently, because their adsorption is highly influenced by factors such as the $\mathrm{pH}$ of the medium and presence of other mycotoxins in the food (Sabater-Vilar et al., 2007).

Table 3 shows the mean values of the activities of the liver enzymes (AST and GGT) worldwide. Enzymatic activities were influenced punctually only at D32 in TG. While AST activity increased only in the interaction time $(p=0.04), G G T$ activity $(p=0.001)$ decreased in the interaction time and treatment interaction $(G G T=0.01)$. There was no interaction time for these activities in CG.

In case of AST activity, it was noted that most of the values measured were within the reference values for the species, including for the $T G$, in which there was a punctual increase of this enzyme at D32 (Kaneko, Harvey, \& Bruss, 2008). As this enzyme is present in the cytosol of hepatocytes, it can be affirmed that most animals did not present lesions that caused rupture of hepatocytes, such as degeneration or necrosis. This demonstrates that although the diet was challenging, it was not able to cause liver lesions, as observed by D'Angelo et al. (2007), in cattle accidentally intoxicated with high doses of AF (above 1,250 ppb of AFB1 per day). Moreover, there were no clinical issues reported in the animals used in the experiments. 
The enzymatic activity of GGT was within the reference values for most animals in both groups (Thrall, 2007). Some animals, both in the CG and TG, showed an increase in GGT activity, which was above the reference for the species initially, but was normalized later. GGT is synthesized in various body tissues; however, most of this serum enzyme comes from the liver, and its increase in some animals could indicate cholestase, hepatic lipidosis, and fasciolose (Thrall, 2007). Its decrease does not perpetuate over time, and the results of its individual analysis are not considered conclusive.

\section{Table 3}

Activity of serum liver enzymes (AST, GGT and LDH) of cows inuntreated (GC) and treated with adsorbent for mycotoxins (TG).

\begin{tabular}{|c|c|c|c|c|c|c|c|c|c|c|c|}
\hline & & & & & Mome & ents & & & & & \\
\hline Varia & les & & DO & D8 & D16 & D24 & D32 & D40 & D48 & D56 & $P^{x}$ \\
\hline & $C G$ & Average & $96,67^{a}$ & $100,11^{a}$ & $89.22 a$ & $79,67^{a}$ & $00,78^{a}$ & $94,56^{a}$ & $106.11^{a}$ & $100.33^{a}$ & 0,38 \\
\hline & U & SEM & 9,37 & 15,12 & 8,27 & 10,04 & 15,86 & 9,55 & 20,15 & 14,17 & \\
\hline & TG & Average & $90.44^{\mathrm{ab}}$ & $84,44^{a}$ & $103.11^{\mathrm{ab}}$ & $82,33^{a}$ & $102,22^{b}$ & $97,89^{a}$ & $99.56^{a}$ & $127,00^{a}$ & 0,04 \\
\hline & SU & SEM & 12,75 & 8,12 & 9,87 & 10,55 & 14,99 & 12,06 & 11,28 & 23,47 & \\
\hline & $P^{y}$ & & 0,83 & 0,24 & 0,06 & 0,97 & 0,24 & 0,27 & 0,30 & 0,11 & \\
\hline & $C G$ & Average & $47,11^{\mathrm{a}}$ & $41,89^{a}$ & $38.56^{a}$ & $45,22^{\mathrm{a}}$ & $33,44^{a}$ & $42,00^{a}$ & $40.33^{a}$ & $45.56^{a}$ & 0,56 \\
\hline & o & SEM & 5,41 & 5,46 & 1,94 & 5,99 & 3,85 & 6,49 & 4,40 & 6,40 & \\
\hline$U^{-1}$ & TG & Average & $61,44^{\mathrm{a}}$ & $28.44^{\mathrm{ab}}$ & $41,00^{\mathrm{a}}$ & $44,56^{a}$ & $20,00^{b}$ & $46,44^{a}$ & $48.56^{a}$ & $40.33^{a}$ & 0,001 \\
\hline & 10 & SEM & 12,09 & 4,37 & 4,60 & 5,66 & 4,40 & 4,40 & 9,61 & 9,61 & \\
\hline & $P^{y}$ & & 0,21 & 0,09 & 0,45 & 0,50 & 0,01 & 0,19 & 0,19 & 0,21 & \\
\hline
\end{tabular}

EPM $=$ Standard error of the mean. $\mathrm{P}^{\mathrm{x}}$ interaction time. $\mathrm{P}^{\mathrm{y}}$ treatment interaction. $\mathrm{CG}=$ control group. TG $=$ treatment group. Different lower-case letters on the same line indicate statistical difference in time interaction. Tukey test $(p<0.05) .1$ Reference Values: AST = 78 - $132 \mathrm{UL}^{-1}$ (KANEKO et al. , 2008), GGT = 0 - 48, U L-1, (THRALL, 2007).

Similarly, Custódio et al. (2017) noted that cattle fed diets containing low levels of mycotoxins, such as $69.5 \mu \mathrm{g} \mathrm{Kg}^{-1}$ of DON and $0.7 \mu \mathrm{gg}^{-1}$ of AF, also showed AST and GGT activities within the reference values for the species, which could indicate absence of liver injury, but not safety of the diet.

The liver function data are shown in Table 4. A point increase in the content of serum protein was observed in both groups on D8, in relation to D0 and D24 $(p<0.05)$ in the interaction time. There was an increase in serum protein content from D24 in TG compared to CG $(p<0.05)$ with respect to treatment interaction, and increased serum albumin from D32 in TG with respect to time interaction $(p<0.05)$ and from D40 with respect to treatment interaction $(p<0.05)$.

Although the reference values for these variables in cattle vary in the literature (Lopes, Biondo, \& Santos, 2007; Kaneko et al., 2008), most animals in both groups presented 
low levels of serum protein and serum albumin initially. While serum protein levels reached the reference parameters in both groups, and were above the reference values for the TG at D16, D40, and D56, serum albumin levels remained below the reference values for most animals in the CG. In the TG, these levels reached the reference values from D24 and went above them only in D48.

Serum proteins and albumins are synthesized by the liver from substrates absorbed from the diet. Hence, situations of low dietary protein levels, failure in intake, inefficient absorption, protein loss owing to gastrointestinal alterations, dehydration, urinary changes, blood loss, or even dysfunctions of its synthesis by liver, could lead to hypoproteinemia and hypoalbuminemia (Lopes etal., 2007). The liver is the main target of mycotoxins, and chronic intoxication induces lesions that are characterized by proliferation and fibrosis of the bile ducts, accompanied by megalocytosis of hepatocytes (Kellerman, Coetzer, Naudé, \& Botha, 2005).

\section{Table 4}

Serum protein and albumin from untreated cows (CG) and treated with adsorbent for mycotoxins (TG).

\begin{tabular}{|c|c|c|c|c|c|c|c|c|c|c|c|}
\hline \multicolumn{12}{|c|}{ Moments } \\
\hline Variables & & & D0 & D8 & D16 & D24 & D32 & D40 & D48 & D56 & $P^{x}$ \\
\hline \multirow{5}{*}{$\begin{array}{c}\text { Serum } \\
\text { protein } \\
\mathrm{g} \mathrm{dL}^{-1}\end{array}$} & \multirow{2}{*}{ CG } & Average & $96,67^{a}$ & $100,11^{a}$ & $89.22^{\mathrm{a}}$ & $79,67^{a}$ & $00,78^{a}$ & $94,56^{a}$ & $106.11^{a}$ & $100.33^{a}$ & 0,38 \\
\hline & & SEM & 9,37 & 15,12 & 8,27 & 10,04 & 15,86 & 9,55 & 20,15 & 14,17 & \\
\hline & \multirow{2}{*}{ TG } & Average & $90.44^{\mathrm{ab}}$ & $84,44^{a}$ & $103.11^{\mathrm{ab}}$ & $82,33^{a}$ & $102,22^{b}$ & $97,89^{a}$ & $99.56^{a}$ & $127,00^{a}$ & 0,04 \\
\hline & & SEM & 12,75 & 8,12 & 9,87 & 10,55 & 14,99 & 12,06 & 11,28 & 23,47 & \\
\hline & $P^{y}$ & & 0,83 & 0,24 & 0,06 & 0,97 & 0,24 & 0,27 & 0,30 & 0,11 & \\
\hline \multirow{5}{*}{$\begin{array}{l}\text { Albumin } \\
\mathrm{g} \mathrm{dL}^{-1}\end{array}$} & \multirow{2}{*}{ CG } & Average & $47,11^{\mathrm{a}}$ & $41,89^{a}$ & $38.56^{a}$ & $45,22^{\mathrm{a}}$ & $33,44^{a}$ & $42,00^{a}$ & $40.33^{a}$ & $45.56^{a}$ & 0,56 \\
\hline & & SEM & 5,41 & 5,46 & 1,94 & 5,99 & 3,85 & 6,49 & 4,40 & 6,40 & \\
\hline & \multirow{2}{*}{ TG } & Average & $61,44^{\mathrm{a}}$ & $28.44^{\mathrm{ab}}$ & $41,00^{\mathrm{a}}$ & $44,56^{a}$ & $20,00^{b}$ & $46,44^{a}$ & $48.56^{a}$ & $40.33^{a}$ & 0,001 \\
\hline & & SEM & 12,09 & 4,37 & 4,60 & 5,66 & 4,40 & 4,40 & 9,61 & 9,61 & \\
\hline & $\mathrm{P}^{y}$ & & 0,21 & 0,09 & 0,45 & 0,50 & 0,01 & 0,19 & 0,19 & 0,21 & \\
\hline
\end{tabular}

$\mathrm{EPM}=$ Standard error of the mean. $\mathrm{P}^{\mathrm{x}}$ interaction time. $\mathrm{P}^{\mathrm{y}}$ treatment interaction. $\mathrm{CG}=$ control group. TG $=$ treatment group. Different lowercase letters in the same line indicate statistical difference in time interaction, Tukey test ( $p<0.05)$. 1- Reference value: Serum protein 6.74-7.46 g dL-1; serum albumin 3.03-3.55 g dL-1 (Kaneko et al., 2008).

As there was no dietary change, and no diarrheas or hyporexias either, it is believed that these changes may be correlated with liver dysfunction.

It is known that hypoalbuminemia and hypoproteinemia due to liver dysfunction only occur when $70 \%$ of liver function is compromised, which is reflected in the clinical manifestations of icteric, edemas, weight loss, and decrease in dairy production, which are alterations not usually observed in animals (Kaneko et al., 2008). Thus, it is believed that the hepatic metabolization of mycotoxins aided by the adsorbent may have contributed to the 
use of nutrients, and protein anabolism did not occur at its maximum efficiency. According to Guo et al. (2019), the increase in LDH associated with decreased protein synthesis and serum albumin would be sufficient to indicate liver alteration; thus, it can be assumed that the animals already presented some hepatic challenge at the beginning of the experiment, which the adsorbent was able to attenuate.

As serum protein and albumin levels went above the reference values at certain time points in TG, another possible hypothesis is that relative dehydration caused by the adsorbent due to its hydrophilicity (Viotti, 2006), could have rummaged more water to the intestinal lumen and consequently impacted such indices, a fact also verified in the erythrogram (Figure 1).

In this analysis, the erythrogram data were within the reference values for the species (Thrall, 2007). It was observed that the treatment promoted a statistically significant increase in the number of red blood cells, hemoglobin, and hematocrit in the treatment interaction compared to the CG between D8 and D32 $(p<0.05)$; however, there was no difference in relation to the interaction time.

Thus, the hypothesis of relative dehydration is supported by the findings of the erythrogram, in which there was an increase in the number of red blood cells, hemoglobin, and hematocrit between D8 and D32 for the TG, a fact that is also observed during dehydration (Stockham \& Scott, 2011).

However, it remains unclear whether the effects observed in the TG in relation to erythropoieis and serum proteins and albumin were due to the relative dehydration caused by the adsorbent or by lower exposure of the liver to mycotoxins that were adsorbed by the product.

Regarding themeanvalues of neutrophil and leukocyte ratio (N/L ratio) (Figure 2), in the $\mathrm{CG}$, one animal presented leukocytosis by neutrophilia and lymphocytosis at D32, one presented leukocytosis by neutrophilia at D48 and D56, and two animals presented mucopurulent nasal secretions, indicating a bacterial infection, probably in the anterior respiratory tract, since no other evident clinical alteration was found, such as apathy, decreased milk production, hyporexia, or fever, which could indicate a more severe condition. In the TG, no animal presented with leukocytosis. Regarding the mean values, there was no influence of adsorbent use on the interaction time or treatment for total leukocyte count and their populations. The CG presented a lower N/L ratio both in the time interaction, and in the treatment interaction at D8, and later, the CG presented a higher proportion of neutrophiles/lymphocytes both in the time interaction, and in the treatment interaction at D48 and D56 ( $p<0.05)$. 

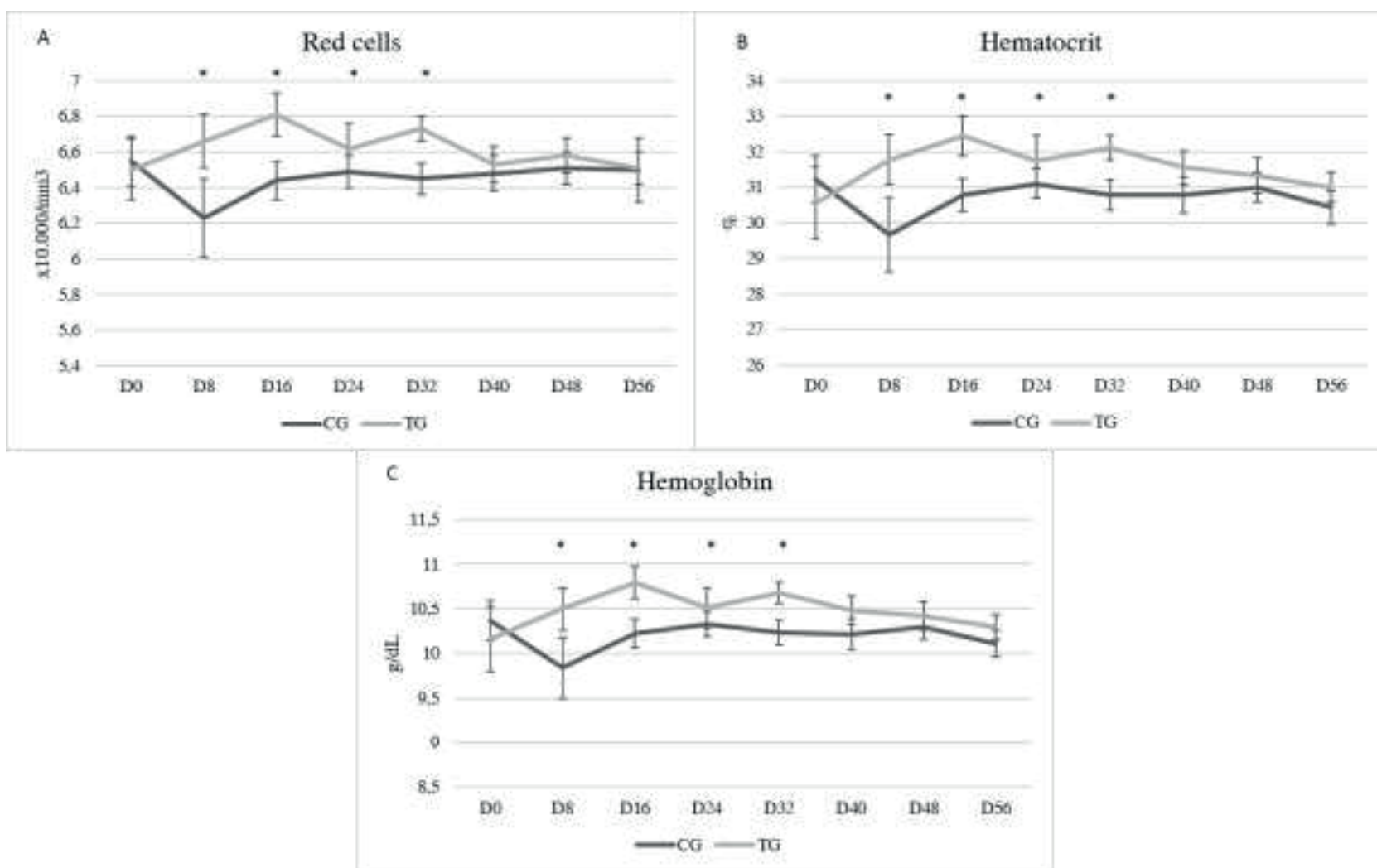

Figure 1. Graphic representation of hematological evaluations related to red blood cells (A), hematocrit $(B)$ and hemoglobin $(C)$, performed in untreated lactating cows $(C G)$ and treated with adsorbent for mycotoxins (TG). * Indicates statistical difference in treatment interaction, Tukey test $(p<0.05)$.

On the leukogram, it was found that adsorbent use had no influence on the mean total leukocyte count and their populations. However, the lower neutrophil/lymphocyte ratio in CG on D8 indicates an overall reduction in the number of neutrophils to the detriment of lymphocytes, indicating a viral or bacterial challenge, which was fought, considering that no animal demonstrated clinical manifestation of the disease in this period. Over time, this ratio was inverted in D48 and D56, when some animals in the CG also presented with leukocytosis due to neutrophilia and mucopurulent nasal secretion, indicating that at least two animals in this group were sick at these time points. 

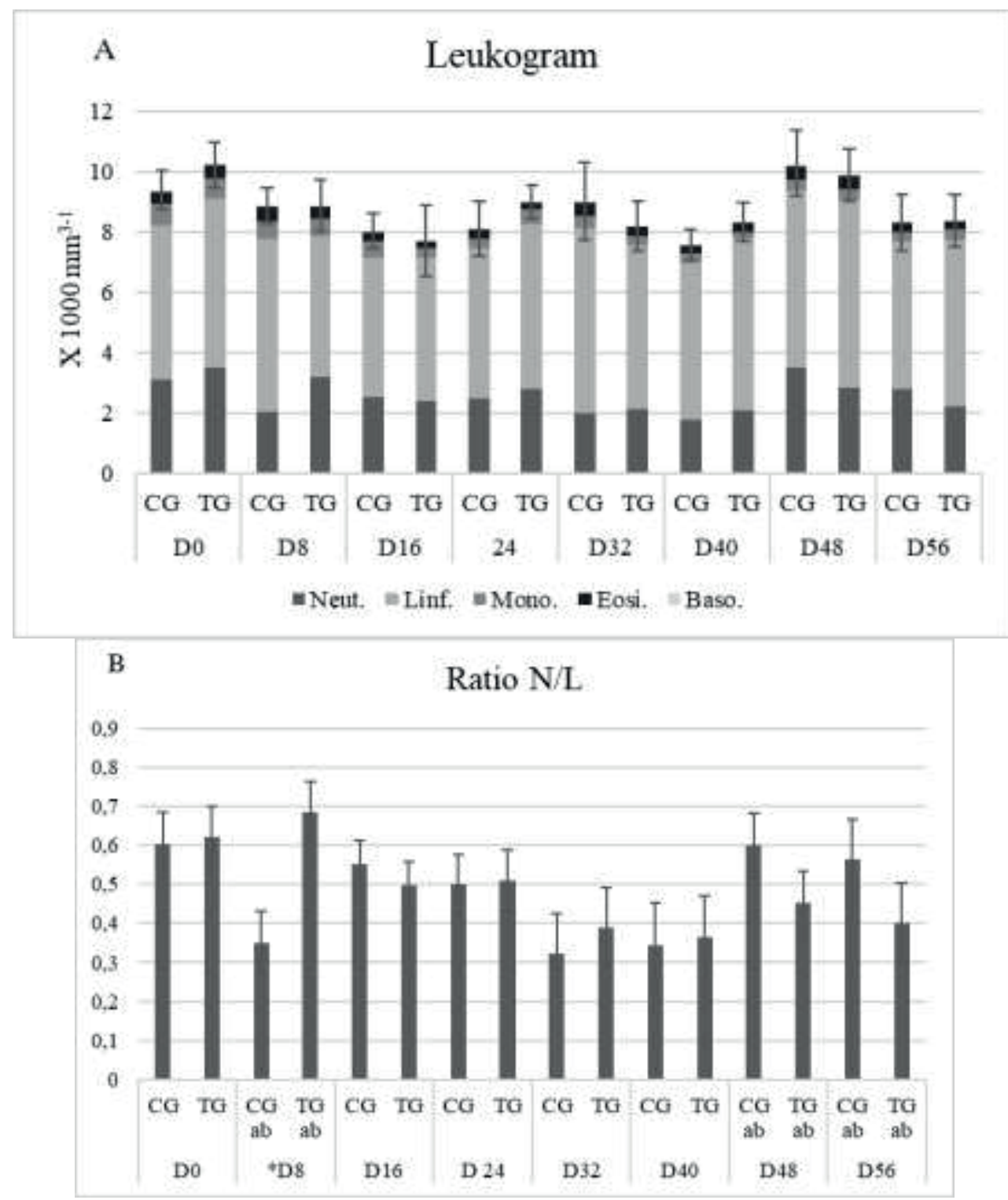

Figure 2. Graphic representation of leukogram of untreated lactating cows (CG) and treated with adsorbent for mycotoxins (TG). Board A- Leucogram. Board B- Neutrophil lymphocyte ratio (N/L ratio) Neut. = Neutrophils; Lymphocytes = Lymphocytes; Mono = monocytes; Eos = Eosinophils; Bas $=$ Basophils.

There was an increase in leukocyte oxidative metabolism (Table 5) in animals treated from D16, in relation to the initial period for TG in the interaction time $(p=0.004)$ and treatment $(p<0.05)$, except at D40, when this function was identical between the groups. 
Table 5

Oxidative metabolism of blood leukocytes of untreated lactating cows (CG) and treated with adsorbent complex for mycotoxins (TG)

$\begin{array}{ccccccccccc}\text { Mo } & & \text { D0 } & \text { D8 } & \text { D16 } & \text { D24 } & \text { D32 } & \text { D40 } & \text { D48 } & \text { D56 } & P^{x} \\ \text { CG } & \text { Average } & 0,421^{\mathrm{a}} & 0,411^{\mathrm{a}} & 0,451^{\mathrm{a}} & 0,419^{\mathrm{a}} & 0,379^{\mathrm{a}} & 0,490^{\mathrm{a}} & 0,395^{\mathrm{a}} & 0,504^{\mathrm{a}} & 0,06 \\ & \text { SEM } & 0,021 & 0,018 & 0,036 & 0,036 & 0,03 & 0,026 & 0,039 & 0,028 & \\ \text { TG } & \text { Average } & 0,421^{\mathrm{a}} & 0,427^{\mathrm{a}} & 0,555^{\mathrm{b}} & 0,613^{\mathrm{b}} & 0,537^{\mathrm{b}} & 0,550^{\mathrm{b}} & 0,497^{\mathrm{b}} & 0,602^{\mathrm{b}} & 0,004 \\ & \text { SEM } & 0,021 & 0,025 & 0,038 & 0,062 & 0,037 & 0,026 & 0,032 & 0,034 & \\ \mathrm{P}^{y} & & 0,42 & 0,6 & 0,05 & 0,01 & 0,004 & 0,52 & 0,05 & 0,04 & \end{array}$

DO = Optical density. MSE = Standard error of the mean. CG = Control group. TG = treatment group, a or b Different lowercase letters on the same line indicate statistical difference in interaction time, Tukey test $(p<0.05)$.

In the analysis of leukogram data combined with oxidative metabolism, we found that the adsorbent improved the immunological capacity of the animals. While the CG showed no change in leukocyte oxidative metabolism over time, an increase in this function was observed from D16 in TG. Oxidative metabolism is a respiratory explosion brought about by phagocytes, such as neutrophils and monocytes. During phagocytosis, oxidizing compounds called reactive oxygen species (ROS) are produced to eliminate internalized pathogens (Tizard, 2014). The NBT colorimetric assay mimics an infection, where blood phagocytes are stimulated with PMA, phagocytose the yellow reagent, and oxidize it into a bluish compound called formazan. At the end of the reaction, leukocytes are dissolved, and the compound is released into the solution, dyeing it blue in proportion to the magnitude of oxidative metabolism (Choi et al., 2006).

Thus, increased leukocyte oxidative metabolism in TG indicates that the treatment increased the ability of animals to fight pathogens, thus becoming less susceptible to infectious diseases, unlike CG (Tizard, 2014). It is known that mycotoxins decrease immunity and resistance to infectious diseases (Oswald et al., 2005) and adsorbents can mitigate the impacts of such toxins, allowing greater efficiency of the immune system (Queiroz, Han, Staples, \& Adesogan, 2012).

Regarding the analyses of milk, its composition did not show any significant alterations, and fat, protein, and lactose levels remained stable, as shown in Table 6. Animals in the TG increased milk production from D16 in relation to the initial period $(p=0.008)$, but there was no treatment interaction. The fat levels in the milk remained stable, even with the increase in the volume produced, with no significance in the treatment or interaction time. Similarly, the other variables did not show any significant differences. There was no influence of time or treatment on protein and lactose levels. 
Table 6

Physical-chemical analysis of milk of untreated lactating cows (CG) and cows treated with the adsorbent complex for mycotoxin (TG)

\begin{tabular}{|c|c|c|c|c|c|c|c|c|c|c|c|}
\hline Milk Data & & & DO & D8 & D16 & D24 & D32 & D40 & D48 & D56 & $P x$ \\
\hline \multirow{5}{*}{$\begin{array}{l}\text { Production } \\
\left(K_{\text {Kg day }}^{-1}\right)\end{array}$} & \multirow{2}{*}{ CG } & Average & $29,88^{a}$ & $29,58^{a}$ & $32,42^{a}$ & $30,78^{a}$ & $29,14^{a}$ & $31,72^{\mathrm{a}}$ & $31.78^{a}$ & $32,44^{a}$ & 0,07 \\
\hline & & SEM & 1,3 & 0,98 & 1,24 & 1,01 & 1,31 & 1,33 & 1,23 & 1,44 & \\
\hline & \multirow{2}{*}{ TG } & Average & $28,86^{a}$ & $31,96^{a}$ & $34,44^{b}$ & $33,14^{b}$ & $33,64^{b}$ & $34,76^{b}$ & $35,40^{b}$ & $35,06^{b}$ & 0,008 \\
\hline & & SEM & 0,7 & 0,85 & 1,08 & 1,27 & 1,11 & 1,33 & 0,94 & 1,06 & \\
\hline & $P^{y}$ & & 0,68 & 0,38 & 0,55 & 0,38 & 0,18 & 0,43 & 0,26 & 0,48 & \\
\hline \multirow{5}{*}{$\begin{array}{l}\text { SCC } \\
\text { Log } 10 \\
\left(x 10^{3} \mathrm{ml}^{-1}\right)\end{array}$} & \multirow{2}{*}{ CG } & Average & $3,73^{a}$ & $4,04^{a}$ & $3,91^{\mathrm{a}}$ & $4,08^{b}$ & $4.07^{\mathrm{ab}}$ & $3,92^{a}$ & $3.82^{\mathrm{a}}$ & $4,29^{b}$ & 0,03 \\
\hline & & SEM & 0,19 & 0,22 & 0,13 & 0,07 & 0,16 & 0,13 & 0,11 & 0,11 & \\
\hline & \multirow{2}{*}{ TG } & Average & $3,78^{a}$ & $3.93^{a b}$ & $3,71^{a}$ & $3,97^{b}$ & $3,79^{a}$ & $3,55^{a}$ & $3.73^{b}$ & $3,68^{a}$ & 0,01 \\
\hline & & SEM & 0,17 & 0,16 & 0,18 & 0,18 & 0,22 & 0,17 & 0,19 & 0,19 & \\
\hline & $P^{y}$ & & 0,88 & 0,59 & 0,43 & 0,96 & 0,36 & 0,63 & 0,94 & 0,16 & \\
\hline \multirow{5}{*}{$\begin{array}{l}\text { Fat } \\
\left(g_{\left.100 g^{-1}\right)}\right.\end{array}$} & \multirow{2}{*}{ CG } & Average & $4,18^{a}$ & $4,05^{a}$ & $4,17^{a}$ & $4,27^{a}$ & $4,24^{a}$ & $4,05^{a}$ & $3.95^{a}$ & $3,83^{a}$ & 0,94 \\
\hline & & SEM & 0,15 & 0,31 & 0,34 & 0,22 & 0,23 & 0,35 & 0,24 & 0,37 & \\
\hline & \multirow{2}{*}{ TG } & Average & $3,89^{a}$ & $4,08^{a}$ & $3,37^{a}$ & $3,55^{\mathrm{a}}$ & $3,50^{\mathrm{a}}$ & $3,49^{a}$ & $3.16^{a}$ & $3,55^{a}$ & 0,54 \\
\hline & & SEM & 0,3 & 0,35 & 0,34 & 0,39 & 0,36 & 0,43 & 0,35 & 0,47 & \\
\hline & $P^{y}$ & & 0,95 & 0,15 & 0,36 & 0,24 & 0,53 & 0,16 & 0,49 & 0,66 & \\
\hline \multirow{5}{*}{$\begin{array}{l}\text { Protein } \\
\left(\mathrm{g} 100 \mathrm{~g}^{-1}\right)\end{array}$} & \multirow{2}{*}{ CG } & Average & $3,40^{a}$ & $3,49^{a}$ & $3,48^{a}$ & $3,30^{a}$ & $3,50^{a}$ & $3,32^{a}$ & $3.52^{a}$ & $3,66^{a}$ & 0,95 \\
\hline & & SEM & 0,199 & 0,23 & 0,18 & 0,20 & 0,17 & 0,26 & 0,22 & 0,23 & \\
\hline & \multirow{2}{*}{ TG } & Average & $4,36^{a}$ & $4,61^{a}$ & $4,56^{a}$ & $4,58^{a}$ & $4,56^{a}$ & $4,65^{a}$ & $4.63^{a}$ & $4,55^{\mathrm{a}}$ & 0,56 \\
\hline & & SEM & 0,44 & 0,21 & 0,24 & 0,14 & 0,26 & 0,23 & 0,27 & 0,29 & \\
\hline & $P^{y}$ & & 0,28 & 0,55 & 0,35 & 0,77 & 0,09 & 0,36 & 0,34 & 0,39 & \\
\hline \multirow{5}{*}{$\begin{array}{l}\text { Lactose } \\
\left(\mathrm{g}_{\left.100 \mathrm{~g}^{-1}\right)}\right.\end{array}$} & \multirow{2}{*}{ CG } & Average & $4,62^{a}$ & $4,71^{a}$ & $4,71^{a}$ & $4,61^{a}$ & $4,70^{a}$ & $4,72^{a}$ & $4.78^{a}$ & $4,72^{a}$ & 0,41 \\
\hline & & SEM & 0,08 & 0,03 & 0,05 & 0,02 & 0,05 & 0,05 & 0,05 & 0,05 & \\
\hline & \multirow{2}{*}{ TG } & Average & $4,36^{a}$ & $4,61^{a}$ & $4,57^{a}$ & $4,59^{a}$ & $4,57^{\mathrm{a}}$ & $4,66^{a}$ & $4.63^{a}$ & $4.57^{a}$ & 0,57 \\
\hline & & SEM & 0,17 & 0,07 & 0,08 & 0,05 & 0,09 & 0,08 & 0,09 & 0,13 & \\
\hline & PAND & & 0,35 & 0,34 & 0,28 & 0,58 & 0,40 & 0,43 & 0,25 & 0,24 & \\
\hline
\end{tabular}

SCC - somatic cell count. SEM - standard error of the mean. $\mathrm{P}^{\mathrm{x}}$ interaction time. $\mathrm{P}^{\mathrm{y}}$ treatment interaction, a or b Different lower-case letters on the same line indicate statistical difference in interaction time, Tukey test $(p<0.05)$.

Regarding SCC, it was found that there was no change in this variable in relation to treatment; however, there were differences observed according to time. SCC increased punctually at D24 compared to D0 and D40 in both groups ( $p<0.05)$. Until D8, there was an animal with subclinical mastitis in each group
(> 200,000 somatic cells). Subsequently, the CG and TG no longer showed subclinical mastitis from D16 and D40, respectively, with no statistical difference in the incidence of mastitis between the groups or between treatments. 
Kiyothong et al. (2012) found that use of adsorbents of mycotoxins (bentonite, diatomite, inactive yeast, and phytogenic and phytolytic substances) led to increased milk production and food intake of dairy cows fed a diet naturally contaminated with mycotoxins (DON, FB1, ZEA, and OTA). This could be the reason for the increase in milk production in this experiment, because, according to these authors, the treated animals may have increased food intake, which would reflect both in the productive indices as well as in the form of increased serum protein and albumin production. Unfortunately, food intake was not measured, and as the animals had free access to food, there could have been an increase in consumption for the treated group, due to the lower liver load brought about by the adsorption of mycotoxins from the diet (Oswald et al., 2005).

Pourmahmoud, Pirmohammadi and Khalilvandi Behroozyar (2019) also found that the adsorbent complex formed by various silicates and extracts from the yeast cell walls (Saccharomyces cerevisiae) caused an increase of $18.30 \%$ in milk production of goats fed diets containing mycotoxins, making it unclear whether this increase was caused by improvements in the liver function, which provided more nutrients to the mammary gland, or due to improvements in ruminal fermentation, which also provides a greater supply of nutrients to the mammary glands.

Regardless of the mechanism, the adsorbent caused an increase in milk production by $17.12 \%$ (6.2 liters of milk per day) in our study. Considering that the cost of the commercial product is estimated at $\mathrm{R} \$ 0.18$ per animal per day, the increase in investment within the production system is justified because of the higher financial return for the producer, especially since the supplement used consisted of only one ingredient, bentonite clay, unlike in case of Pourmahmoud et al. (2019).

The adsorbent did not have any influence on SCC. Similarly, Xiong et al. (2018), using an adsorbent based on amystosilicate in dairy cows subjected for long periods to diets contaminated with AFB1 ", found no variation in SCC count in animals with an average of 4,000 cell $\mathrm{mL}^{-1}( \pm 0.089)$. This may have occurred because the animals already had low SCC due to management, feeding, and sanity within the desirable standards.

The reason behind the observation that even with the increase in milk production in the $\mathrm{TG}$, the physical-chemical variables of milk did not change, could be that at the property on which the experiment was carried out, these parameters were already at desirable levels within a productive system.

\section{Conclusions}

The use of $30 \mathrm{~g}$ of the adsorbent clay based on aluminosilicate improved the health of dairy cows fed a diet containing naturally produced mycotoxins ZEA, DON, AF, and $F B$. The increase in milk production was not accompanied by improved milk quality parameters. The use of this adsorbent is justified due to the economic returns resulting from the improved immunity and productivity of the animals.

Thanks

Financial support Capes 0001. 


\section{References}

Bennett, J. W., \& Klich, M. (2003). Clinical Microbiology Review. Mycotoxins, 16(1), 497-516. doi: 10.1128/CMR.16.3.497-516

Cano-Sancho, G., Marin, S., Ramos, A. J., Peris-Vicente, J., \& Sanchis, V. (2010). Occurrence of aflatoxin M1 and exposure assessment in Catalonia (Spain). Revista Iberoamericana de Micología, 27(1), 130135. doi: 10.1016/j.riam.2010.05.003

Choi, H. S., Kim, J. W., Cha, Y. N., \& Kim, C. (2006). A quantitative nitroblue tetrazolium assay for determining intracellular superoxide anion production in phagocytic cells. Journal of Immunoassay and Immunochemistry, 27(1), 31-44. doi: 10. 1080/15321810500403722

Custódio, L., Prados, L. F., Yiannikouris, J., Holder, V. B., Pettigrew, J. E, Kuritza, L. N.,... Siqueira, G. R. (2019). Mycotoxin contamination of diets for beef cattle finishing in feedlot. Brazilian Journal of Animal Science, 48(1), e20190079. doi: $10.1590 / \mathrm{rbz} 4820190079$

Custódio, L., Figueira, D. N., Gloria, E. M., Holder, V. B., Yiannikouris, A., Pettigrew, J. E.,... Siqueira, G. R. (2017). Survey of mycotoxin contamination in feedlot diets in Brazil. Journal of Animal Science, 95(4), 19-19. doi: 10.2527/asasann.2017.038

D'Angelo, A., Bellino, C., Alborali, G. L., Biancardi, A., Borrelli, A., Capucchio, M.T.,... Cagnasso, A. (2007). Neurological signs associated with aflatoxicosis in Piedmontese calves. Veterinary Record, 160(20), 698-700. doi: 10.1136/vr.160.20.698

Dadalt, A. L. L., \& Primieri, C. (2020). Mycotoxin levels in corn silage in western Paraná.
Brazilian Veterinary Medicine Archives, 3(1), 30-38. Retrieved from http://www. themaetscientia.fag.edu.br/index.php/ ABMVFAG/article/view/1150

Dawson, K. A., Evans, J., \& Kudupoj, E. M. (2006). Understanding the adsorption characteristics of yeast cell wall preparations associated with mycotoxin binding. Nutritional Biotechnology in The Feed and Food Industries, 22(1), 169-181. Retrieved from https: https://en.engormix. com/mycotoxins/articles/understandingadsorption-characteristics-yeast-t33 495.html

Flores, G. V. B., Thomaz, G. R., Horner, W. Netto, Rossi, S. P., Strickle, F., \& Bertagnon, H. G. (2019). Effect of Enterococcus faecium and Saccharomyces cerevisiae on immunological response, hematological parameters and weight gain of calves fed corn silage. Veterinary and Animal Science, 26(1), 1-11. doi: 10.35172/rvz. 2019.v26.353

Franciscato, C., Lopes, S. T. A., Santurio, J. M., Wolkmer, P., Maciel, R. M., Paula, M. T.,... Costa, M. M. (2006). Serum concentrations of minerals and liver and kidney functions of chickens intoxicated with aflatoxin and treated with sordic montmorillonite. Brazilian Agricultural Research, 41(11), 1573-1577. doi: 10.1590/S0100-204X20 06001100001

Guo, X., Wen, F., Qiao, Q., Zheng, N., Saive, M., \& Fauconnier, M. L., (2019). A novel graphene oxide-based aptasensor for amplified fluorescent detection of aflatoxin M1 in milk powder. Sensors, 19(18), 38-40. doi: 10.3390/s19183840

Intrução Normativa $\mathrm{n}^{\circ} 88$ de 26 de março de 2021, Ministério da Saúde/Agência 
Nacional de Vigilância Sanitária/Diretoria Colegiada - Diário Oficial da União. Estabelece os limites máximos tolerados (LMT) de contaminantes em alimentos. Recuperado de https://www.in.gov.br/en/ web/dou/-/instrucao-normativa-in-n-88de-26-de-marco-de-2021-311655598

Jovaisiene, J., Bakutis, B., Baliukoniene, V., \& Gerulis, G., (2016) Fusarium and Aspergillus mycotoxins effects on dairy cow health, performance and the efficacy of Anti-Mycotoxin Additive. Polish Journal of Veterinary Sciences, 19(1), 79-87. doi: 10.1515/pjvs-2016-0011

Kaneko, J. J., Harvey, J., \& Bruss, M. L. (2008). Clinical biochemistry of domestic animals. San Diego: Elsevier.

Kellerman, T. S., Coetzer, J. A. W., Naudé, T. W., \& Botha, C. J. (2005). Plant poisonings and Mycotoxicoses of livestock in southern Africa. Cape Town: Oxford University Press.

Kiyothong, K., Rowlinson, P., Wanapat, M., \& Khampa, S. (2012). Effect of mycotoxin deactivator product supplementation on dairy cows. Animal Production Science, 52(9), 832-841. doi: 10.1071/AN11205

Kutz, R. E., Sampson, J. D., Pompeu, L. B., Ledoux, D. R., Spain, J. N., Vázquez-Añón, M., \& Rottinghaus, G. E. (2009). Efficacy of Solis, NovasilPlus, and MTB-100 to reduce aflatoxin $\mathrm{M} 1$ levels in milk of early to mid-lactation dairy cows fed aflatoxin B1. Journal of Dairy Science, 92(8), 59-63. doi: 10.3168/jds.2009-2031

Lopes, S. T. A., Biondo, A. W., \& Santos, A. P. (2007). Veterinary clinical pathology. (Manual). Santa Maria: UFSM.
Migliorati, L., Abeni, F., Cattaneo, M. P., Tornielli, C., \& Pirlo, G. (2007). Effects of adsorbents in dairy cow diet on milk quality and cheese-making properties. Italian Journal of Animal Science, 6(1), 460-462. doi: 10.4081/ijas.2007.1s.460

Murphy, P. A., Hendrich, S., Landgren, C., \& Bryant, C. M. (2006). Food mycotoxins: an update. Journal of Food Science, 71(5), 51-65. doi: 10.1111/j.1750-3841.2006. 00052.x

Oswald, I. P., Marin, D. E., Bouhet, S., Pinton, P., Taranu, I., \& Accensi, F. (2005). Immunotoxicological risk of mycotoxins for domestic animals. Food Additives Contaminantes, 22(4), 354-360. doi: 10. $1080 / 02652030500058320$

Pereira, M. M. G., Carvalho, E. P., Prado, G., Rosa, C. A. R., Veloso, T., Souza, L. A. F., \& Ribeiro, J. M. M. (2005). Aflatoxins in cattle feed and milk samples from lavras region, Minas Gerais -Brazil. Science and Agrotechnology, 29(1), 106-112. doi: 10. 1590/S1413-70542005000100013

Pourmahmoud, B., Pirmohammadi, R., \& Khalilvandi Behroozyar, H. (2019). Effects of different toxin adsorbents on the amount of diazinon residue in white grape pomace and milk production and composition and toxin residues in mohabadi lactating goats. Iranian Journal of Applied Animal Science, 9(4), 677-685. Retrieved from: http://ijas.iaurasht.ac.ir/ article_669378.html

Prandini, A., Tansini, G., Sigolo, S., Filippi, L., Laporta, M., \& Piva, G. (2009). On the occurrence of aflatoxin M1 in milk and dairy products. Food and Chemical Toxicology, 47(5), 984-991. doi: 10.1016/ j.fct.2007.10.005 
Queiroz, O. C., Han, J. H., Staples, C. R., \& Adesogan, A. T. (2012). Effect of adding a mycotoxin-sequestering agent on milk aflatoxin $\mathrm{M}_{1}$ concentration and the performance and immune response of dairy cattle fed an aflatoxin $\mathrm{B}_{1}$ contaminated diet. Journal of Dairy Science, 95(10), 5901-5908. doi: 10.3168/ jds.2011-5287

Sabater-Vilar, M., Malekinejad, H., Selman, M. H. J., \& Van der Doelen, M. A. M. (2007) In vitro assessment of adsorbents aiming to prevent deoxynivalenol and zearalenone mycotoxicoses. Mycopathologia, 163(2), 81. doi: 10.1007/s11046-007-0093-6

Sampaio, I. B. M. (2002). Estatística Aplicada à Experimentação Animal. Fundação de Ensino e Pesquisa em Medicina Veterinária e Zootecnia. Belo Horizonte, MG: Embrapa Gado de Leite.

Schneider, A. F., Mayer, J. K., Volpato, J., \& Gewehr, C. E. (2019). Seeric minerals, bone morphometric characteristics and bone mineral deposition of broilers fed a diet with bentonite inclusion. Brazilian Archive of Veterinary Medicine and Animal Science, 71(2), 594-602. doi: 10. 1590/1678-4162-9968

Stockham, S. L., \& Scott, M. A. (2011). Fundamentals of veterinary clinical pathology (2nd ed.). Rio de Janeiro: Koogan Guanabara.

Thrall, M. A. (2007). Hematology and veterinary clinical biochemistry. São Paulo, SP: Roca.
Tizard, I. R. (2014). Innate immunity: neutrophils and phagocytosis. In T. Ian (Ed,), Veterinary immunology (pp. 30-40). Rio de Janeiro, RJ: Elsevier.

Tyska, D., Mallmann, A. O., Vidal, J. K., Almeida, C. A. A., Gressler, L. T., \& Mallmann, C. A. (2021). Multivariate method for prediction of fumonisins B1 and B2 and zearalenone in Brazilian maize using Near Infrared Spectroscopy (NIR). PLOS ONE, 16(1), e0244957. doi: 10.1371/journal. pone.0244957

Viotti, G.C.A. (2006) Desenvolvimento e Caracterização de Argilas Organofílicas para uso em Alimentação Animal como Adsorvente Inativador de Micotoxinas: Aflatoxina B1 e Fumonisina B1. Tese de doutorado, Programa de Pós-Graduação da Universidade Federal de Santa Catarina-UFSC, Florianópolis, SC, Brasil, Recuperado de https://repositorio.ufsc. br/handle/123456789/89509

Wang, Q., Zhang, Y., Zheng, N., Guo, L., Song, X., Zhao, S., \& Wang, J. (2019). Biological system responses of dairy cows to aflatoxin B1 exposure revealed with metabolomic changes in multiple biofluids. Toxins, 11(2), 77. doi: 10.3390/ toxins 11020077

Xiong, L., Wang, Y. M., Zhou, H. L., \& Liu, J. X. (2018). Effects of dietary adsorbent on milk aflatoxin M1 content and the health of lactating dairy cows exposed to longterm aflatoxin B1 challenge. Journal of Dairy Science, 101(10), 8944-8953. doi: 10.3168/jds.2018-14645 